\title{
FOLLICULAR DYNAMICS IN ZEBU CATTLE ${ }^{1}$
}

\author{
JOÃO HENRIQUE MOREIRA VIANA ${ }^{2}$, ADEMIR DE MORAES FERREIRA ${ }^{3}$, \\ WANDERLEI FERREIRA DE SÁ ${ }^{3}$ and LUIZ SÉRGIO DE ALMEIDA CAMARGO 4
}

\begin{abstract}
The aim of this study was to investigate the follicular dynamics during estrous cycle in Gir breed (Bos indicus) cows. Follicular growth and atresia during estrous cycle were evaluated using a portable ultrasound device. Luteal activity was evaluated by serum progesterone levels. Cycles with two $(6.67 \%)$, three $(60.00 \%)$, four $(26.67 \%)$ and five $(6.67 \%)$ follicular waves were observed. There was no difference $(\mathrm{P}>0.05)$ in dominant or subordinate follicles growth or atresia rates among follicular waves. The maximum diameter of the ovulatory follicle was higher than the diameter of the other dominant follicles in cycles with four waves, and higher than the diameter of the second dominant follicle in cycles with three waves $(\mathrm{P}<0.05)$. There was no difference $(\mathrm{P}>0.05)$ in estrous cycle length $(21.11 \pm 1.76$ and $22.25 \pm 1.71$ days) or progesterone levels during diestrous $(4.48 \pm 1.45$ and $5.08 \pm 1.40 \mathrm{ng} / \mathrm{mL})$ between cycles with three or four waves. Follicular dynamics in Gir cattle is characterized by a higher incidence of cycles with three or four waves, associated with a low persistence of the dominant follicle.
\end{abstract}

Index terms: bovines, Gir breed, oestrous cycle, ovaries, ovarian follicles, ultrasonics.

\section{DINÂMICA FOLICULAR EM VACAS ZEBUÍNAS}

\begin{abstract}
RESUMO - Objetivou-se neste trabalho estudar a dinâmica folicular em vacas da raça Gir (Bos indicus). $\mathrm{O}$ crescimento e a atresia folicular foram monitorados diariamente ao longo de ciclos estrais completos ( $\mathrm{n}=15)$, utilizando-se um aparelho portátil de ultra-som. A atividade luteal em cada ciclo foi avaliada pela determinação do nível de progesterona plasmática. Foram observados ciclos com duas $(6,67 \%)$, três $(60,00 \%)$, quatro $(26,67 \%)$ e cinco $(6,67 \%)$ ondas de crescimento folicular. Não houve diferença significativa $(\mathrm{P}>0,05)$ nas taxas de crescimento e atresia de folículos dominantes ou subordinados, entre ondas. O diâmetro máximo do folículo ovulatório foi maior $(\mathrm{P}<0,05)$ que o dos demais folículos dominantes nos ciclos com quatro ondas e do que o diâmetro do folículo dominante da segunda onda nos ciclos com três ondas. Não houve diferença significativa $(\mathrm{P}>0,05)$ no comprimento do ciclo $(21,11 \pm 1,76$ e $22,25 \pm 1,71$ dias) ou na concentração de progesterona durante o diestro $(4,48 \pm 1,45$ e $5,08 \pm 1,40 \mathrm{ng} / \mathrm{mL})$, entre ciclos com três ou quatro ondas de crescimento. Esses resultados demonstraram que a dinâmica folicular na raça Gir é caracterizada pela predominância de ciclos com três ou quatro ondas de crescimento folicular, associados à baixa persistência dos folículos dominantes das ondas intermediárias.
\end{abstract}

Termos para indexação: bovinos, raça Gir, ciclo estral, ovários, folículos ovarianos, ultra-som.

${ }^{1}$ Accepted for publication on January 21, 2000.

Financial support by $\mathrm{CNPq}$ and FAPEMIG.

${ }^{2}$ Veterinarian, M.Sc., Embrapa-Centro Nacional de Pesquisa de Gado de Leite (CNPGL), Rua Eugênio do Nascimento, 610, Dom Bosco, CEP 36038-330 Juiz de Fora, MG. CNPq Scholarship. E-mail: jhmviana@cnpgl.embrapa.br

${ }^{3}$ Veterinarian, D.Sc., Embrapa-CNPGL.

E-mail: ademirmf@cnpgl.embrapa.br

${ }^{4}$ Veterinarian, M.Sc., Embrapa-CNPGL.

E-mail: camargo@cnpgl.embrapa.br

\section{INTRODUCTION}

Follicular growth in cattle is not continuous, as initially suggested by studies on ovaries recovered in slaughterhouses (Matton et al., 1981), but cyclic and dependent on the estrous cycle stage (Pierson \& Ginther, 1987a; Fortune, 1994). Ovarian follicular dynamics on cows and heifers is characterized by waves of follicular growth and regression during the 
estrous cycle (Savio et al., 1988; Ginther et al., 1989; Knopf et al., 1989; Taylor \& Rajamahendran, 1991). Each wave is preceded by a small increase on serum FSH concentrations, and the following recruitment of a pool of follicles within 2 to $5 \mathrm{~mm}$ which progress development (Ginther et al., 1997). After the initial growth period, a functional dominant follicle is selected and subordinate follicles begin atresia (Fortune, 1994). Bovine usually shows two (Ginther et al., 1989; Knopf et al., 1989; Taylor \& Rajamahendran, 1991) or three (Savio et al., 1988; Sirois \& Fortune, 1988) follicular waves during estrous cycle, but cycles with one (Savio et al., 1988) or four (Sirois \& Fortune, 1988) follicular waves are also found. The main characteristics of follicular growth and atresia are affected by wave order (Savio et al., 1988; Ginther et al., 1989) and can also change among animals due to many factors like breed (Figueiredo et al., 1997), reproductive stage (Roche \& Boland, 1991), season (Badinga et al., 1994; Zeitoun et al., 1996), heat stress (Wilson et al., 1998), energy balance (Rhodes et al., 1995) and body score condition (Burke et al., 1998).

Follicular dynamics is one of the most important subjects on ovarian physiology, and was largely studied in European breeds (Bos taurus) (Savio et al., 1988; Sirois \& Fortune, 1988; Ginther et al., 1989; Knopf et al., 1989; Roche \& Boland, 1991; Taylor \& Rajamahendran, 1991; Badinga et al., 1994). However, the number of reports on Zebu cattle (Bos indicus) and its crossbreeds is limited, specially on the most important breeds for Brazilian dairy and beef production (Figueiredo et al., 1997; Gambini et al., 1998). Reproductive physiology of Zebu cows is not identical to European breed cows, and differences were reported on characteristics like luteal tissue area (Pathiraja et al., 1986), dominant follicle diameter (Barros et al., 1995; Figueiredo et al., 1997), estrous length (Medrano et al., 1996) and ovulation moment (Pinheiro et al., 1998). The knowledge of these differences is very important to the establishment of the correct evaluation parameters and management procedures for Zebu cows, and also to the development of new technologies to increase herd reproductive performance (Hahn, 1992; Armstrong, 1993; Fortune, 1993; Adams, 1994).

The objective of this study was to evaluate follicular growth and regression characteristics during the estrous cycle in Gir cows.

\section{MATERIAL AND METHODS}

This study was performed in the experimental field Fazenda Santa Mônica, which belongs to Embrapa-Centro Nacional de Pesquisa de Gado de Leite (CNPGL), and is located in Valença, RJ, Brazil. The experimental field is situated at $22^{\circ} 21^{\prime}$ of latitude and $43^{\circ} 42^{\prime}$ of longitude, at an altitude of $437.19 \mathrm{~m}$, and presents a CWA weather according to Köppen classification (Brasil, 1992), with a precipitation of $1.280 \mathrm{~mm} /$ year and medium temperature of $22.5^{\circ} \mathrm{C}$. The cows used $(\mathrm{n}=15)$ were of Gir breed, multiparous, non-lactating, with body score condition, according to Ferreira \& Torres (1993), ranging from 3.5 to 5.0 (mean of $3.77 \pm 0.70$ ), and weight ranging from 357 to $515 \mathrm{~kg}$ (mean of $448.93 \pm 45.69 \mathrm{~kg}$ ). All animals were previously submitted to clinical and gynecological examinations, and only those with no clinical or reproductive abnormalities were used. Cows received food supplement of corn silage, in order to keep initial body score condition or to obtain a positive energy balance during experimental period (June to September). Estrous behavior was checked twice a day, with the aid of a herdmate.

Follicular dynamics was evaluated daily, using an ultrasound portable device, equipped with a $5 / 7.5 \mathrm{MHz}$ linear bifrequential probe (frequence of $7.5 \mathrm{MHz}$ was used as standard). In each evaluation, follicles with a diameter higher than $3 \mathrm{~mm}$ were identified and measured by the calipers of the ultrasound device. The dominant follicle was characterized by the divergence of its growth rate when compared to the subordinate follicles of the same wave. Data obtained were graphically represented to characterize the number of follicular waves. The day of the ovulation which preceded the estrous cycle was considered as day zero. Luteal activity was evaluated by serum progesterone concentrations. Blood samples were obtained every other day by coccigea artery punction, using vacutainer tubs containing $15 \mu \mathrm{L}$ of heparin. Immediately after puncture, the samples were centrifuged at $2.000 \mathrm{rpm}$ for 20 minutes, and the plasma obtained was identified and stocked at $-20^{\circ} \mathrm{C}$. The analyses were performed by the radioimunoessay technique, using a commercial kit for determination of progesterone by $\mathrm{I}^{1253}$, in the Radioimunoessay Laboratory of Embrapa-CNPGL.

For each follicular wave, the following parameters were evaluated: day of wave detection, maximum diameter of the dominant follicle (DF) and of the larger subordinate follicle (SF), day of the DF maximum diameter, DF and SF growth and atresia rates $(\mathrm{mm} /$ day), day of DF selection, day of DF atresia, DF growth and atresia period length, wave length and SF persistence (days). Growth and atresia rates were determined dividing the variation observed 
on follicular diameter by the number of days of observation.

Data were grouped according to the number of follicular waves present in each estrous cycle. Among animals with the same number of follicular waves per cycle, parameters were evaluated by variance analysis (ANOVA), by a randomized block schedule, in which cow characterizes the block. Differences among waves were evaluated by Tukey's test. Differences on follicular growth and atresia characteristics among animals with different follicular wave number were evaluated by F test. The relationship between the number of waves and estrous cycle length, and between dominant follicle diameter and follicular wave length, was estimated by Pearson's correlation method. Statistical analyses were performed using the software SAEG (Euclides, 1982). Results are shown as mean \pm standard deviation (S.D.).

\section{RESULTS AND DISCUSSION}

The estrous cycles evaluated presented the characteristic pattern of follicular growth waves, with the initial development of a group of 3 to $5 \mathrm{~mm}$ follicles, followed by the selection, development and atresia of a dominant follicle. From these estrous cycles $(n=15)$, one $(6.67 \%)$ presented two follicular waves (Fig. 1); nine (60\%) presented three follicular waves (Fig. 2); four (26.67\%) presented four follicular waves (Fig. 3) and one (6.67\%) presented five follicular waves (Fig. 4). The amount of cows with cycles with four follicular waves is reduced (Sirois \& Fortune, 1988). A higher prevalence of cycles with three follicular waves, however, was observed by many authors in European (Savio et al., 1988; Sirois \& Fortune, 1988) and Zebu cows (Gambini et al., 1998).

The main characteristics of the follicular dynamics in the cows with three follicular waves are shown on Table 1 . The first wave emerged on day $0.78 \pm 0.44$ of the cycle, few time after ovulation (day 0 ). The selection of the dominant follicle, characterized by the divergence among the dominant and subordinate follicles growth rate (Ginther et al., 1996, 1997), occurred on day $4.13 \pm 0.99$. The establishment of the follicular dominance mechanism requires the production of inhibin and estradiol by the DF, with consequent reduction in FSH serum concentration, limiting the maximum diameter reached by the subordinated follicles ( $7.25 \pm 0.71 \mathrm{~mm}$ in the first wave) and inducing their atresia. The dominant follicle reached its maximum diameter on day $6.45 \pm 0.88$ and entered atresia on day $7.89 \pm 0.78$, showing a short period of stabilization or plateau. This growth pattern differs from that reported for two wave cows, in which the first DF regression occurs only after days 11 or 13 (Ginther et al., 1989; Knopf et al., 1989; Taylor \& Rajamahendran, 1991), but was similar to that ob-

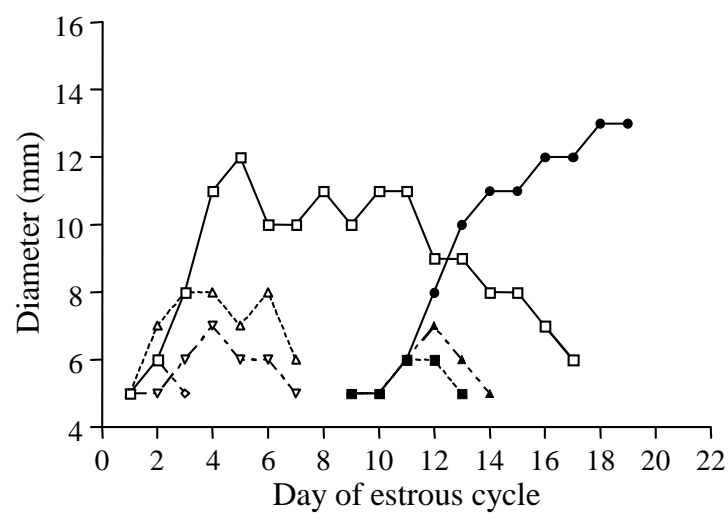

FIG. 1. Follicular dynamic of a Gir cow ( $\left.\operatorname{cow} \mathrm{n}^{0} \mathbf{5 7 6 6}\right)$ with two follicular waves during estrous cycle. Solid lines (licles, and dotted lines (-----) subordinate follicles. Open symbols $(\nabla, \square, \triangle)$ represent follicles from the first follicular wave, and solid symbols $(\bullet, \square, \Delta)$, follicles from the second wave.

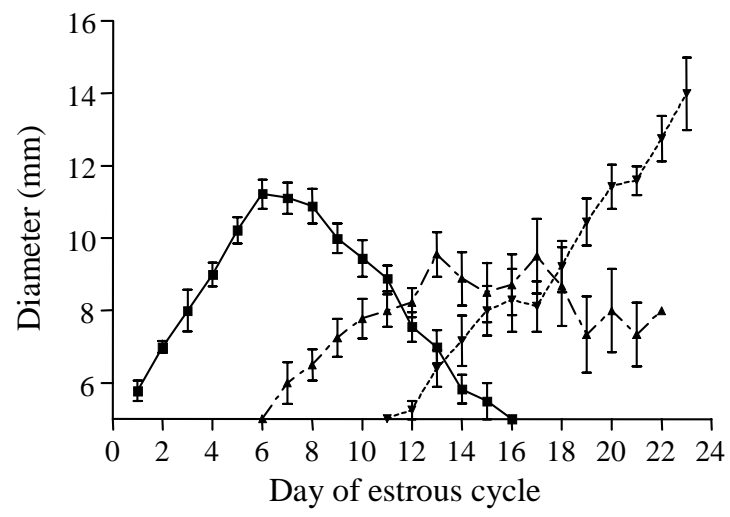

FIG. 2. Pattern of growth and atresia of dominant follicles from Gir cows with three follicular waves during estrous cycle. Lines represent the first ((----) follicular waves. 
served in cycles with three follicular waves (Savio et al., 1988; Sirois \& Fortune, 1988; Gambini et al., 1998). The second wave emerged on day $7.11 \pm 1.05$, with the respective dominant follicle being selected on day $11.33 \pm 2.06$, reaching its maximum diameter on day $12.89 \pm 3.06$ and beginning atresia on day $15.55 \pm 3.36$, with intervals among events similar to those observed on the first wave. The third wave (ovulatory) emerged on day $13.22 \pm 2.44$, with the dominant follicle being selected on day $16.89 \pm 2.85$, and reaching its maximum diameter on day $20.44 \pm 1.42$. Other studies which evaluated cows with three

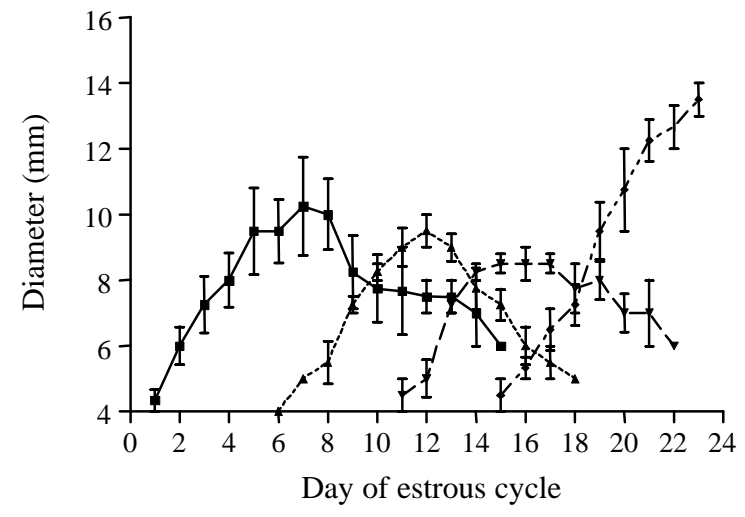

FIG. 3. Pattern of growth and atresia of dominant follicles from Gir cows with four follicular waves during estrous cycle. Lines represent the first (- $)$, second (----), third (----) and fourth (------) follicular waves.

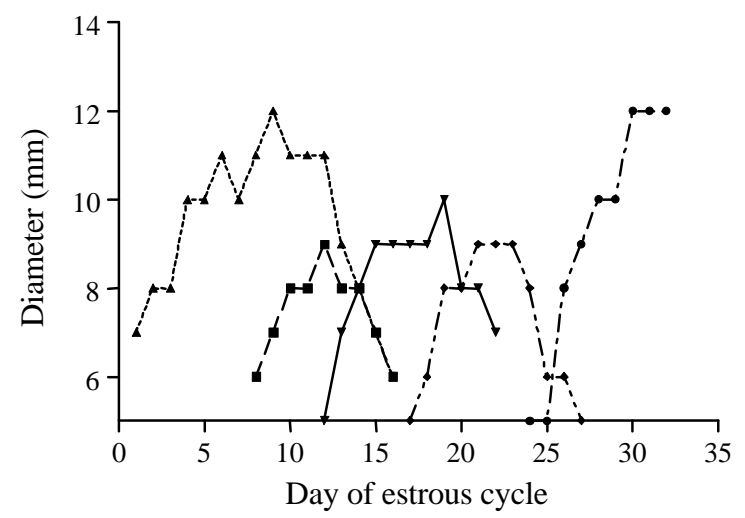

FIG. 4. Follicular dynamic of a Gir cow (cow no 5774) with five follicular waves during estrous cycle. Lines represent the first (-....), second $(--)$, third $(-)$, fourth $\left(----_{-}\right)$ and fifth (-- - - ) follicular waves. follicular waves (Sirois \& Fortune, 1988; Ginther et al., 1989) agree with the appearance of waves at intervals of approximately seven days, which occur due to transient increases on serum FSH concentration (Ginther et al., 1996). There was no difference $(\mathrm{P}>0.05)$ on dominant or subordinated follicle growth or atresia rates among follicular waves, but the DF maximum diameter of the second wave was smaller $(\mathrm{P}<0.05)$ than the diameter of the other DFs (Table 1). This difference may be related to the fact that the second wave emerges during the period of higher progesterone production by the corpus luteum, whereas the first and third waves emerge, respectively, during the luteogenic and luteolytic periods. The mean diameter of the DFs was lower than that reported for cows from European breeds, as observed by Figueiredo et al. (1997) and Gambini et al. (1998). The third follicular wave finished with the ovulation of the dominant follicle. The ovulatory follicle is the functional dominant follicle present at luteolysis (Quirk et al., 1986), indicating that luteolysis occurred between selection and the day in which the third DF reached its maximum diameter. The absence of the atresia period of the DF determinated the shorter length of this wave $(\mathrm{P}<0.01)$.

Table 2 shows the characteristics of follicular dynamics in the cows with four follicular waves during the estrous cycle. The first wave emerged on day $1.25 \pm 0.50$ of the cycle and was followed by selection of the DF on day $5.75 \pm 1.71$, growth until day $7.00 \pm 1.41$ and onset of atresia on day $8.25 \pm 0.96$, in a pattern similar to that observed in cycles with three waves. The intermediate waves (second and third) emerged on days $7.25 \pm 0.96$ and $11.25 \pm 0.96$, with the respective dominant follicles being selected on days $10.25 \pm 0.96$ and $14.75 \pm 0.96$, respectively. These waves were characterized by a short growth period after selection of the DFs, with the maximum diameter occurring on days $11.25 \pm 0.96$ and $15.50 \pm 1.29$; and by a short period of plateau, with atresia beginning on days $12.00 \pm 0.82$ and $17.00 \pm 1.41$. The fourth wave emerged on day $15.00 \pm 1.41$, with the ovulatory follicle being selected on day $18.75 \pm 1.26$, and reaching its maximum diameter on day $21.25 \pm 1.71$. As observed on the three wave cycles, there was no difference $(P>0.05)$ in growth or atresia rates of the dominant or subordinate follicles among follicular waves, but the 
maximum diameter of the ovulatory follicle was higher than the diameter of the dominant follicles of the other waves $(\mathrm{P}<0.05)$. The length of the fourth follicular wave was shorter than the first, but was similar to that observed for the intermediate waves $(\mathrm{P}<0.05)$, reflecting the lower persistence of these waves, considering that the ovulatory wave has no atresia period.

Many authors (Ginther et al., 1989; Taylor \& Rajamahendran, 1991; Figueiredo et al., 1997) characterized the luteal phase length as the main determinant of the number of folicular waves. As it keeps high concentrations of progesterone, corpus luteum blocks ovulation of functional dominant follicles, inducing their atresia and the onset of a new follicular wave. Supporting this hypothesis, factors like the artificial lengthening of estrous cycle by exogenous progesterone administration (Sirois \& Fortune, 1990; Taylor et al., 1993) and the maintenance of corpus luteum during initial gestation (Roche \& Boland,
1991; Ginther, 1993), result in the continuous onset of new follicular waves. In the present study, however, there was no difference on estrous cycle length between cows with three or four follicular waves during estrous cycle $(21.11 \pm 1.76$ and $22.25 \pm 1.71$ days, respectively; $\mathrm{P}>0.05$ ), despite a tendency of increase in the number of follicular waves with the lengthening of the cycle $(r=0.449 ; \mathrm{P}=0.053)$ was observed. Only one animal presented a characteristic lengthening of the luteal phase, what resulted in an estrous cycle of 32 days and in the appearance of five follicular waves (Fig. 4). The characteristics of follicular growth and atresia observed in this cycle were similar to those observed in the other cycles studied, and coherent to what is expected with artificial lengthening of the cycle (Sirois \& Fortune, 1990). The cow with two follicular waves presented an estrous cycle of 19 days.

Factors other than luteal phase length may have been responsible for the variation on the number of

TABLE 1. Characteristics of follicular waves, growth and atresia of dominant follicles and of the largest subordinate follicle in cows with three follicular waves during estrous cycle (mean \pm standard deviation) $)^{1}$.

\begin{tabular}{lccc}
\hline Characteristic & \multicolumn{3}{c}{ Follicular wave } \\
\cline { 2 - 4 } & First & Second & Third \\
\hline Wave onset (day) & $0.78 \pm 0.44 \mathrm{a}$ & $7.11 \pm 1.05 \mathrm{~b}$ & $13.22 \pm 2.44 \mathrm{c}$ \\
Wave length (days) & $13.00 \pm 1.58 \mathrm{a}$ & $11.44 \pm 2.19 \mathrm{a}$ & $7.67 \pm 1.80 \mathrm{~b}$ \\
Dominant follicle & & & \\
Maximum diameter (mm) & $11.78 \pm 1.20 \mathrm{a}$ & $10.44 \pm 2.13 \mathrm{~b}$ & $12.44 \pm 1.59 \mathrm{a}$ \\
Day of maximum diameter & $6.45 \pm 0.88$ & $12.89 \pm 3.06$ & $20.44 \pm 1.42$ \\
Growth rate (mm/day) & $1.03 \pm 0.24 \mathrm{a}$ & $1.07 \pm 0.23 \mathrm{a}$ & $1.08 \pm 0.26 \mathrm{a}$ \\
Day of divergence & $4.13 \pm 0.99$ & $11.33 \pm 2.06$ & $16.89 \pm 2.85$ \\
Length of growth phase (days) & $5.67 \pm 0.71 \mathrm{a}$ & $5.22 \pm 1.72 \mathrm{a}$ & $7.00 \pm 1.50 \mathrm{a}$ \\
Onset of atresia (day) & $7.89 \pm 0.78$ & $15.55 \pm 3.36$ & - \\
Atresia rate (mm/day) & $0.97 \pm 0.26 \mathrm{a}$ & $0.96 \pm 0.33 \mathrm{a}$ & - \\
Length of atresia (days) & $7.00 \pm 1.32 \mathrm{a}$ & $4.78 \pm 1.30 \mathrm{~b}$ & - \\
Largest subordinate follicle & & & $7.00 \pm 1.32 \mathrm{a}$ \\
Maximum diameter (mm) & $7.25 \pm 0.71 \mathrm{a}$ & $7.22 \pm 1.39 \mathrm{a}$ & $1.01 \pm 0.33 \mathrm{a}$ \\
Growth rate (mm/day) & $1.00 \pm 0.50 \mathrm{a}$ & $1.03 \pm 0.16 \mathrm{a}$ & $1.14 \pm 0.42 \mathrm{a}$ \\
Atresia rate (mm/day) & $1.21 \pm 0.50 \mathrm{a}$ & $1.24 \pm 0.50 \mathrm{a}$ & $4.67 \pm 1.80 \mathrm{a}$ \\
Persistence (days) & $4.75 \pm 1.28 \mathrm{a}$ & $5.33 \pm 1.87 \mathrm{a}$ & \\
\hline
\end{tabular}

${ }^{1}$ Values followed by different letters within rows differ $(\mathrm{P}<0.05)$. 
follicular waves observed. The lower diameter reached by intermediate wave dominant follicles when compared to the diameter of ovulatory follicles $(\mathrm{P}<0.05)$, associated with a shorter plateau phase, may have contributed to increase the number of waves (Tables 1 e 2). When the length of the estrous cycle is constant, a shorter interval between waves results in a higher number of follicular waves per cycle (Ginther et al., 1989). As growth and atresia rates did not differ among waves $(\mathrm{P}>0.05)$, the lower maximum diameter determined a shorter persistency of DF and, consequently, the precocious appearance of a new wave. The fact that the maximum diameter of the intermediate wave dominant follicles presented a significant positive correlation with their length $(r=0.72$ and 0.96 for the second and third waves, respectively, $\mathrm{P}<0.05)$ is coherent with this hypothesis. Ginther et al. (1996) observed that FSH release inhibition is proportional to the maximum size of the wave DF, and that larger DFs were related to higher intervals between follicular waves. The dominant follicle is functional only during growth or early plateau phases, period in which it can induce atresia of subordinate follicles, and also block follicular recruitment and emerging of a new wave (Fortune, 1994; Ginther et al., 1996). Precocious induction of DF atresia by GnRH, LH or estradiol administration (Thatcher et al., 1993; Bo et al., 1995), or DF ablation (Boni et al., 1997), results in the establishment of a new wave, and are used as methods of follicular growth synchronization (Armstrong, 1993; Bodensteiner et al., 1996). The subordinate follicles maximum diameter observed in this study, and also their growth and atresia rates, were not different among waves and among cows with different number of waves per cycle $(\mathrm{P}>0.05)$, and similar to what is reported on the literature (Ginther et al., 1989, 1996; Figueiredo et al., 1997). Hence, the lower persistence of the DF seems to be determinated after selection period.

TABLE 2. Characteristics of follicular waves, growth and atresia of dominant follicles and of the largest subordinate follicle in cows with four follicular waves during estrous cycle (mean \pm standard deviation) ${ }^{1}$.

\begin{tabular}{lcccc}
\hline Characteristic & \multicolumn{4}{c}{ Follicular wave } \\
\cline { 2 - 5 } & First & Second & Third & Fourth \\
\hline Wave onset (day) & $1.25 \pm 0.50 \mathrm{a}$ & $7.25 \pm 0.96 \mathrm{~b}$ & $11.25 \pm 0.96 \mathrm{c}$ & $15.00 \pm 1.41 \mathrm{~d}$ \\
Wave length (days) & $11.50 \pm 2.38 \mathrm{a}$ & $9.50 \pm 1.92 \mathrm{ab}$ & $9.25 \pm 1.71 \mathrm{ab}$ & $7.25 \pm 1.89 \mathrm{~b}$ \\
Dominant follicle & & & \\
Maximum diameter (mm) & $10.75 \pm 2.50 \mathrm{a}$ & $9.75 \pm 0.96 \mathrm{a}$ & $9.00 \pm 0.82 \mathrm{a}$ & $13.25 \pm 0.96 \mathrm{~b}$ \\
Day of maximum diameter & $7.00 \pm 1.41$ & $11.25 \pm 0.96$ & $15.50 \pm 1.29$ & $21.25 \pm 1.71$ \\
Growth rate (mm/day) & $1.09 \pm 0.43 \mathrm{a}$ & $1.42 \pm 0.39 \mathrm{a}$ & $1.02 \pm 0.17 \mathrm{a}$ & $1.32 \pm 0.21 \mathrm{a}$ \\
Day of divergence & $5.75 \pm 1.71$ & $10.25 \pm 0.96$ & $14.75 \pm 0.96$ & $18.75 \pm 1.26$ \\
Length of growth phase (days) & $5.75 \pm 0.96 \mathrm{ab}$ & $4.00 \pm 1.63 \mathrm{~b}$ & $4.25 \pm 0.96 \mathrm{ab}$ & $6.00 \pm 0.82 \mathrm{a}$ \\
Onset of atresia (day) & $8.25 \pm 0.96$ & $12.00 \pm 0.82$ & $17.00 \pm 1.41$ & - \\
Atresia rate (mm/day) & $1.02 \pm 0.30 \mathrm{a}$ & $0.92 \pm 0.29 \mathrm{a}$ & $0.76 \pm 0.07 \mathrm{a}$ & - \\
Length of atresia (days) & $5.50 \pm 2.08 \mathrm{a}$ & $5.50 \pm 1.92 \mathrm{a}$ & $4.50 \pm 1.29 \mathrm{a}$ & - \\
Largest subordinate follicle & & & & \\
Maximum diameter (mm) & $7.50 \pm 0.58 \mathrm{a}$ & $7.50 \pm 1.29 \mathrm{a}$ & $6.75 \pm 0.96 \mathrm{a}$ & $7.25 \pm 2.50 \mathrm{a}$ \\
Growth rate (mm/day) & $0.73 \pm 0.25 \mathrm{a}$ & $0.98 \pm 0.24 \mathrm{a}$ & $0.88 \pm 0.25 \mathrm{a}$ & $0.92 \pm 0.17 \mathrm{a}$ \\
Atresia rate (mm/day) & $1.38 \pm 0.75 \mathrm{a}$ & $1.67 \pm 0.47 \mathrm{a}$ & $1.25 \pm 0.50 \mathrm{a}$ & $1.00 \pm 0.00 \mathrm{a}$ \\
Persistence (days) & $6.00 \pm 0.82 \mathrm{a}$ & $4.75 \pm 2.22 \mathrm{a}$ & $4.25 \pm 1.89 \mathrm{a}$ & $4.50 \pm 2.65 \mathrm{a}$ \\
\hline
\end{tabular}

1 Values followed by different letters within rows differ $(\mathrm{P}<0.05)$. 
Differences on maximum diameter and on growth rates among DFs of different waves are also observed in European cows with three follicular waves (Savio et al., 1988; Sirois \& Fortune, 1988; Taylor \& Rajamahendran, 1991). The first wave DF and the ovulatory follicle develop in the periods of luteal formation and regression, respectively. The lower concentration of progesterone present during these periods may be associated with higher gonadotrophic concentrations and, consequently, with higher diameter and persistence of the DFs. The final follicular growth and maturation are dependent on a high frequency of LH pulses (Roche \& Boland, 1991), which do not occur during diestrous due to the negative feed-back effect of the progesterone. The maintenance of artificially low progesterone concentrations results in an increase of LH pulse frequency and in the appearance of the persistent dominant follicle phenomena (Sirois \& Fortune, 1990). There was, however, no difference on progesterone concentration during diestrous between cows with three or four follicular waves $(4.48 \pm 1.45$ and $5.08 \pm 1.40 \mathrm{ng} / \mathrm{mL}$, respectively; $\mathrm{P}>0.05)$. These values are similar to those observed on other studies with cows presenting different follicular wave patterns (Sirois \& Fortune, 1988; Figueiredo et al., 1997).

Body score condition is one of the factors that can affect DF persistence (Rhodes et al., 1995). Energy balance affect IGF, insulin and GH systemic levels and alters LH pulse frequency and follicular growth (Grimard et al., 1995). Rhodes et al. (1995) observed a reduction on maximum diameter, growth rate and persistence of DFs on Zebu cows within negative energy balance. In the present study, however, there was no difference $(\mathrm{P}>0.05)$ on live weight or body score condition between cows with three or four follicular waves. There was not significant correlation $(\mathrm{P}>0.05)$ between weight or body score condition and maximum diameter or persistence of DF from different waves as well. The cows evaluated presented a minimum body score condition, characterized as good according to Ferreira \& Torres (1993), and were fed to keep or increase weight. The number of follicular waves, in this study, appears to be not related to variations on cow's energy status.

The dominant follicle developed in the right ovary in a frequency of $73.33 \%, 80 \%$ and $64.28 \%$ during the first, second and third waves, respectively. The higher incidence of dominant follicles in the right ovary on all the follicular waves was coherent with the high frequency of corpora lutea present in this ovary observed in this $(66.67 \%)$ and other studies (Pierson \& Ginther, 1987b; Viana et al., 1997). Successive follicular waves, however, alternated between ovaries, resulting in a low percentage of DFs identified in the same ovary of the DF of the preceding wave (from $53.33 \%$ to $57.14 \%$ ), making it impossible to predict the position of the emergence of the next wave.

\section{CONCLUSIONS}

1. Follicular dynamics on Gir cattle is characterized by a higher number of follicular waves during the estrous cycle.

2. The higher number of follicular waves is associated with a low persistence of the dominant follicles from intermediate waves.

\section{REFERENCES}

ADAMS, G.P. Control of ovarian follicular wave dynamics in cattle: implication for syncronization \& superstimulation. Theriogenology, New York, v.41, n.1, p.19-24, 1994.

ARMSTRONG, D.T. Recent advances in superovulation of cattle. Theriogenology, New York, v.39, n.1, p.7-24, 1993.

BADINGA, L.; THATCHER, W.W.; WILCOX, C.J.; MORRIS, G.; ENTWISTLE, K.; WOLFENSON, D. Effect of season on follicular dynamics and plasma concentrations of estradiol-17b, progesterone and luteinizing hormone in lactating holstein cows. Theriogenology, New York, v.42, n.8, p.1263-1274, 1994.

BARROS, C.M.; FIGUEIREDO, R.A.; PINHEIRO, O.L. Estro, ovulação e dinâmica folicular em zebuínos. Revista Brasileira de Reprodução Animal, Belo Horizonte, v.19, n.1/2, p.9-22, 1995.

BO, G.A.; ADAMS, G.P.; PIERSON, R.A.; MAPLETOFT, R.J. Exogenous control of follicular wave emergence in cattle. Theriogenology, New York, v.43, n.1, p.31-40, 1995. 
BODENSTEINER, K.J.; KOT, K.; WILTBANK, M.C.; GINTHER, O.J. Synchronization of emergence of follicular waves in cattle. Theriogenology, New York, v.45, n.6, p.1115-1128, 1996.

BONI, R.; ROELOFSEN, M.W.M.; PIETERSE, M.C.; KOGUT, J.; KRUIP, T.A.M. Follicular dynamics, repeatability and predictability of follicular recruitment in cows undergoing repeated follicular puncture. Theriogenology, New York, v.48, n.2, p.277-289, 1997.

BRASIL. Ministério da Agricultura e Reforma Agrária. Departamento Nacional de Meteorologia. Normas climatológicas (1961-1990). Brasília, 1992. 84p.

BURKE, J.M.; HAMPTON, J.H.; STAPLES, C.R.; THATCHER, W.W. Body condition influences maintenance of a persistent first wave dominant follicle in dairy cattle. Theriogenology, New York, v.49, n.4, p.751-760, 1998.

EUCLIDES, R.F. Sistema de análise estatística e genética (SAEG). Viçosa : UFV, 1982. 68p.

FERREIRA, A.M.; TORRES, C.A.A. Perda de peso corporal e cessação da atividade ovariana luteínica cíclica em vacas mestiças leiteiras. Pesquisa Agropecuária Brasileira, Brasília, v.28, n.3, p.411-418, mar. 1993.

FIGUEIREDO, R.A.; BARROS, C.M.; PINHEIRO, O.L.; SOLER, J.M.P. Ovarian follicular dynamics in Nelore breed (Bos indicus) cattle. Theriogenology, New York, v.47, n.8, p.1489-1505, 1997.

FORTUNE, J.E. Follicular dynamics during the bovine estrous cycle: a limiting factor in improvement of fertility? Animal Reproduction Science, Amsterdam, v.33, n.1/4, p.111-125, 1993.

FORTUNE, J.E. Ovarian follicular growth and development in mammals. Biology of Reproduction, Madison, v.50, n.2, p.225-232, 1994.

GAMBINI, A.L.G.; MOREIRA, M.B.P.; CASTILHO, C.; BARROS, C.M. Desenvolvimento folicular e sincronização da ovulação em vacas da raça Gir. Revista Brasileira de Reprodução Animal, Belo Horizonte, v. 22, n.4, p.201-210, 1998.

GINTHER, O.J. A method for characterizing ultrasonically-derived follicular data in heifers. Theriogenology, New York, v.39, n.2, p.363-371, 1993.

GINTHER, O.J.; KNOPF, L.; KASTELIC, J.P. Temporal association among ovarian events in cattle during oestrous cycles with two and three follicular waves. Journal of Reproduction and Fertility, Cambridge, Grã-Bretanha, v.87, n.1, p.223-230, 1989.

GINTHER, O.J.; KOT, K.; KULICK, L.J.; WILTBANK, M.C. Emergence and deviation of follicles during the development of follicular waves in cattle. Theriogenology, New York, v.48, n.1, p.75-87, 1997.

GINTHER, O.J.; WILTBANK, M.C.; FRICKE, P.M.; GIBBONS, J.R.; KOT, K. Selection of the dominant follicle in cattle. Biology of Reproduction, Madison, v.55, n.6, p.1187-1194, 1996.

GRIMARD, B.; HUMBLOT, P.; PONTER, A.A.; MIALOT, J.P.; SAUVANT, D.; THIBIER, M. Influence of postpartum energy restriction on energy status, plasma LH and oestradiol secretion and follicular development in suckled beef cows. Journal of Reproduction and Fertility, Cambridge, GrãBretanha, v.104, n.1, p.173-179, 1995.

HAHN, J. Attempts to explain and reduce variability of superovulation. Theriogenology, New York, v.38, n.2, p.269-275, 1992.

KNOPF, L.; KASTELIC, J.P.; SCHALLENBERGER, E.; GINTHER, O.J. Ovarian follicular dynamics in heifers: test of two wave hypothesis by ultrasonically monitoring individual follicles. Domestic Animal Endocrinology, New York, v.6, n.2, p.111-119, 1989.

MATTON, P.; ADELAKOUN, V.; COUTURE, Y.; DUFOUR, J.J. Growth and replacement of the bovine ovarian follicles during the estrous cycle. Journal of Animal Science, Champaign, v.52, n.4, p.813-819, 1981.

MEDRANO, E.A.; HERNANDEZ, O.; LAMOTHE, C.; GALINA, C.S. Evidence of asynchrony in the onset of signs of oestrus in zebu cattle treated with a progestogen ear implant. Research in Veterinary Science, London, v.60, n.1, p.51-54, 1996.

PATHIRAJA, N.; OYEDIPE, E.O.; VOH JUNIOR, A.A.; DAWUDA, P.M. Accuracy of rectal palpation in the diagnosis of corpora lutea in Zebu cows. British Veterinary Journal, London, v.142, n.5, p.467-471, 1986.

PIERSON, R.A.; GINTHER, O.J. Follicular populations during the estrous cycle in heifers. I. Influence of day. Animal Reproduction Science, Amsterdam, v.14, n.1/4, p.165-176, 1987a. 
PIERSON, R.A.; GINTHER, J.O. Follicular populations during the estrous cycle in heifers. II. Influence of right and left sides and intraovarian effect of the corpus luteum. Animal Reproduction Science, Amsterdam, v.14, n.1/4, p.177-186, 1987b.

PINHEIRO, O.L.; BARROS, C.M.; FIGUEIREDO, R.A.; VALLE, E.R.; ENCARNAÇÃO, R.O.; PADOVANI, C.R. Estrus behavior and the estrusto-ovulation interval in Nelore cattle (Bos indicus) with natural estrus or estrus induced with prostaglandina F2a or norgestomet and estradiol valerate. Theriogenology, New York, v.49, n.3, p.667-681, 1998.

QUIRK, S.M.; HICKEY, G.J.; FORTUNE, J.E. Growth and regression of ovarian follicles during the follicular phase of the oestrous cycle in heifers undergoing spontaneous and PGF-2 ${ }^{\text {a }}$ induced luteolysis. Journal of Reproduction and Fertility, Cambridge, GrãBretanha, v.77, n.1, p.211-219, 1986.

RHODES, F.M.; FITZPATRICK, L.A.; ENTWISTLE, K.W.; DE'ATH, G. Sequential changes in ovarian follicular dynamics in Bos indicus heifers before and after nutritional anoestrus. Journal of Reproduction and Fertility, Cambridge, Grã-Bretanha, v.104, n.1, p.41-49, 1995.

ROCHE, J.F.; BOLAND, M.P. Turnover of dominant follicles in cattle of different reproductive states. Theriogenology, New York, v.35, n.1, p.81-90, 1991.

SAVIO, J.D.; KEENAN, L.; BOLAND, M.P.; ROCHE, J.F. Pattern of growth of dominant follicles during the oestrous cycle of heifers. Journal of Reproduction and Fertility, Cambridge, Grã-Bretanha, v.83, n.2, p.663-671, 1988.

SIROIS, J.; FORTUNE, J.E. Lengthening the bovine estrous cycle with low leves of exogenous progesterone: a model for studying ovarian follicular domi- nance. Endocrinology, Bethesda, v.127, n.2, p.916-925, 1990.

SIROIS, J.; FORTUNE, J.E. Ovarian follicular dynamics during the oestrous cycle in heifers monitored by real time ultrasonography. Biology of Reproduction, Madison, v.39, n.2, p.308-317, 1988.

TAYLOR, C.; RAJAMAHENDRAN, R. Follicular dynamics, corpus luteum growth and regression in lactating dairy cattle. Canadian Journal of Animal Science, Ottawa, v.71, n.1, p.61-68, 1991.

TAYLOR, C.; RAJAMAHENDRAN, R.; WALTON, J.S. Ovarian follicular dynamics and plasma luteinizing hormone concentrations in norgestomet-treated heifers. Animal Reproduction Science, Amsterdam, v.32, n.3/4, p.173-184, 1993.

THATCHER, W.W.; DROST, M.; SAVIO, J.D.; MacMILLAN， K.L.; ENTWISTLE， K.W.; SCHMITT, E.J.; DE LA SOTA, R.L.; MORRIS, G.R. New clinical uses of GnRH and its analogues in cattle. Animal Reproduction Science, Amsterdam, v.33, n.1/4, p.27-49, 1993.

VIANA, J.H.M.; TORRES, C.A.A.; FERNANDES, C.A.C.; FERREIRA, A.M. Relação do diâmetro folicular com a resposta à sincronização de estro em novilhas. Revista Brasileira de Reprodução Animal, Belo Horizonte, v.21, n.4, p.15-20, 1997.

WILSON, S.J.; MARION, R.S.; SPAIN, J.N.; SPIERS, D.E.; KEISLER, D.H.; LUCY, M.C. Effects of controlled heat stress on ovarian function of dairy cattle. 1. Lactating cows. Journal of Dairy Science, Champaign, v.81, n.8, p.2124-2131, 1998.

ZEITOUN, M.M.; RODRIGUEZ, H.F.; RANDEL, R.D. Effect of season on ovarian follicular dynamics in Brahman cows. Theriogenology, New York, v.45, n.8, p.1577-1581, 1996. 